\title{
The Development of the Theory of Human Capital in the Historical Dimension
}

\author{
M.M. Khaykin ${ }^{1}$ A.A. Lapinskas ${ }^{1}$ O.A. Kochergina ${ }^{2, *}$
}

\author{
${ }^{1}$ Department of Economic Theory, Saint-Petersburg Mining University, Saint-Petersburg, Russia \\ ${ }^{2}$ Department of Foreign Languages, Saint-Petersburg Mining University, Saint-Petersburg, Russia \\ *Corresponding author. Email: Kochergina_OA@pers.spmi.ru
}

\begin{abstract}
The paper deals with the main stages of the formation of the theory of human capital in works of L. Walras, J.M. Clark, F. List, D. Ricardo, and J. McCulloch who showed the influence of the theories of marginal utility, supply and demand, costs, etc. on the development of human capital. The source of the nation's wealth is "mental capital", i.e. discoveries, inventions, achievements in science and art. G. McLeod emphasized the importance of employee competence, A. Marshall introduced the concept of "personal capital".

The essence of human capital is understood ambiguously: a) it is a person as a set of characteristics, b) only his ability to work. The transition to innovative production, an increase in the share of intellectual, highly professional labor costs, etc. contributed to the formation of a full-fledged (classical) theory of human capital. In parallel, the institutional theory of human capital was formed, in which a special role was given to the social environment. On its basis, the foundations of other areas of human capital theory were laid, such as the economy of education, knowledge, and intellectual property. Human capital has been interpreted in an expanded way.
\end{abstract}

Keywords: human, mental, personal capital, competence, ability to work, innovative production, intellectual costs, profitability of the educational system

\section{INTRODUCTION}

The foundations for the formation of the concept of human capital were laid in the works of the founders of classical economic theory: W. Petty, A. Smith, and D. Ricardo. They were the first to introduce into science the ideas of the importance of the labor force, human abilities, and education for the growth of the country's wealth and its population.

W. Petty was the first to introduce and explore the category of "living acting human forces" [1]. On the one hand, he considered it in the context of national wealth, being the most important factor in the growth of the country's wealth, and on the other hand, as an integral part of it. A. Smith emphasized the predominant role of human abilities in relation to the material factors of production. He wrote: "An increase in the productivity of useful labor depends, first of all, on the dexterity and skill of the worker, and then on the improvement of the machines and tools he works with" [2]. D. Riccardo noted the necessity and role of education of a person and population in the economic growth of the country [3].

The ideas of the founders of the world economic thought about the "human factor" of the economic development of society were later used by Karl Marx. Having agreed with the ideas of the founders of classical economic theory about the role of labor in the economy, he understood labor as "a set of physical and spiritual abilities" of workers that are used in the production process [4]. However, Marx further developed these ideas. He justified the need and importance of using special production and significant investments in creating a workforce.

Currently, some major experts believe that many modern economists completely ignore the ideas of Marx about labor theory of value in matters of disclosing the essence and content of the category of "human capital". It's hard for us to agree with that. Working in the era of industrial society, already at that time Karl Marx called the person himself the main capital. In the era of post-industrial society, the category of "human capital" is filled with new qualitative content.

\section{METHODS OF RESEARCH}

The following methods of economic research have been used in the paper: historical and logical, analysis and synthesis. These methods are usually used as complementary methods. The article analyzes the socioeconomic problems of the formation of the theory of 
The English economist and lawyer Henry Dunning McLeod considered exchange relations as the main source of social value. He assigned a special role in the economic growth of the state to credit and banking operations. In this regard, the competence of the employee such as their knowledge, experience, and mental abilities in these areas played a decisive role in the prosperity of the population [10].

L. Walras, J. McCulloch, J. H. Thünen, T. Winstein, W. Farr, and I. Fischer were of the opinion that human capital is the person himself, and not his qualities such as education, abilities, etc. Later, this position was held by A. Marshall. He introduced the concept of "personal capital", referring to a person with physical strength, abilities, and skills that contribute to the growth of labor productivity [11]. However, in general, A. Marshall's economic views rejected the concept of human capital as a defining, basic concept in the system of economic relations.

Other economists, such as F. List, J.S. Walsh, J. S. Mill under human capital understood not the person himself, but his ability to work, i.e. education, qualifications, skills. Some abilities are natural, others are acquired by a person in the process of their life activity. This position was developed in the economic views of R. Dornbush, S. Fischer, and K. Shmanlezi, who attributed to human capital not only the physical and labor abilities of a person, but also their spiritual and ideological features such as cultural, psychological, and moral ones. An important role was played by personal characteristics of the individual in the context of social environment, during the process of making management decisions, by their readiness to take responsibility, as well as their concentration and determination in the most complex and unusual situations. Currently, this is the basic idea of many management specialists in the formation of the image of a modern manager in an organization, including the one at the level of senior management of an economic entity.

Since the early 1900s, economists working within the framework of the concept of human capital have made the first attempts to quantify the effectiveness of human capital in the economy. They began to widely use economic, mathematical and statistical tools in such issues as human value, the impact of the national education system on the country's economic growth, family costs associated with rising economic value of a person, the formation and use of public spending necessary for the upbringing and education of the population. A great contribution to the study of these issues was made by L. Dublin, F. Cram, I. Fischer, and S. H. Forsyth. Certain provisions of the economic views of these major economists were used later in the formation of the modern theory of human capital. 
The formation of the theory of human capital as an independent scientific field is connected with foreign studies of the 60 s of the 20th century. This was facilitated by the special socio-economic conditions prevailing in the second half of the last century such as:

1. The transition to innovative production as a result of high achievements of scientific and technical progress. This led to an increase in the role of complex work and special skills of workers, which in turn led to a change of the role and place of labor in the production process.

2. As a result of profound changes in the content of production processes in many areas of public life, the share of intellectual, highly professional labor costs of employees has become increasingly important in the structure of the cost of the final product. The high material intensity of the product in many economic processes has become inferior to the high "intellectual and professional intensity" (which in practice is manifested in the growth of labor intensity, business income, public funds, etc.).

3. Acceleration of the processes of humanization of social and economic relations in the most developed countries of the world, the stability and credibility of the "idea of human value" at all levels of economic management - in social and economic systems of different types and kinds.

4. Accumulated theoretical and methodological potential of human capital concepts in world economic thought. It made it possible to critically assess the state of scientific thought in the field of human capital concepts and create a new independent scientific direction-the theory of human capital- on the basis of them, taking into account the new socio-economic conditions in society.

The founders of the modern theory of human capital are Nobel Prize winners in 1979 and 1992, American scientists and economists T. Schultz and G. Becker respectively.

The first definition of human capital belongs to $T$. Schultz. His fame is associated with the publication in the open press of two works in 1960 and 1961: "Formation of education capital" [12] and "Investments in human capital". In the work "Investments in human capital", T. Schultz wrote: "The concept of capital comes from the presence of something that really exists, which has the economic ability to provide future services that have some value. Understanding capital as something that provides future services allows us to proceed with the subsequent division of the whole into two parts: human and nonhuman capital." [13]

The concept of human capital by T. Schultz is reduced to several key points.
1. "Human capital" is an additional source of income that is created with the help of knowledge, skills, and abilities of a person.

2. Education is one of the forms of capital, the most important factor that provides economic growth and at the same time a separate source of growth, i.e. outside institutions, subjects of the institutional environment.

3. The capital of education is human capital because it is inseparable from a person.

4. Education as capital is a source of future satisfaction and (or) earnings.

5. To improve the quality characteristics of the workforce, additional investments in education are needed.

6. Investing in education is one of the investments in production factors that create a surplus product.

G. Becker developed the theory of human capital. He made the greatest contribution to this scientific field and is therefore considered to be the universally recognized creator of the scientific school within the framework of the concept of human capital. In his book "Investing in human capital", published in 1962, Harry Becker wrote that human capital is formed by investing in people. Among the main areas of investment, he considered education, training in the workplace, health care costs, migration, search for information about prices and income [14]. In his opinion, these expenses contribute to the development of productive power, intellectual and cultural potential of a person in various ways.

Soon, G. Becker's book "Human capital: theoretical and empirical analysis" published in 1964 was recognized as "classics" of the theory of human capital. It became fundamental for further research by G. Becker and his followers, including representatives of other schools of the concept of human capital. Thanks to G. Becker and his followers, the validity of the ideas of profitability of a high-quality educational system for the national economy in the long-term time interval was proved. This was the basis for approving and implementing the policy of state investment in education.

The concept of "human capital" in science is very ambiguous. Thus, the Nobel Prize winner in Economics G. S. Becker considered human capital inseparably with its owner - the employee. By human capital, he understood the stock of knowledge of the employee, during whose labor process an increase in income is formed [15]. This implies that the process of productive consumption of human capital is inseparable from its owner. The condition for obtaining income from human capital is the labor effort of the employee. The amount of human capital is 
a special place in the functioning of human capital was given to the social environment and social interactions.

In the 1970s-1990s, two approaches to assessing the economic role of education at different levels of economic management were recognized in the wide scientific community.

1. The method of cross-country comparisons. It was successfully tested by A. Andersen, S. Bennett, M. Bohm, M. Kaiser, and D. McClelland. Its idea is to apply international statistics and take into account the features of the functioning models of different types of States. In this case, we are talking about managing socio-economic systems at the mega- and macro levels of management.

2. The method of accounting for production requirements. Its authors were A. Berg, V. Rawlins, and J. Scoville, L. Willman, S. Bowles, D. Gordon, G. Gintis, R. Edwards. The method assumed maximum consideration of the interests of companies in the implementation of their goals and objectives. Thus, an attempt to quantify the importance of education in the economic performance of business entities was made at the micro level of management.

In the 1980s, research continued on the effectiveness of using specific human capital. In particular, a comprehensive analysis was made of the relationship between companies' additional investments in personnel education, the dynamics of their salaries, geographical mobility of employees, and the efficiency of their work in the workplace [19].

At the turn of the last century, foreign researchers analyzed the impact of investment in education on specific forms of human capital at the level of corporate governance of a firm in developed economies. During this period, the works of K. Wang, G. Grayson, N. Gerland, J. Mintzer, O. Nordhaug, G. Psacharopoulos, and T. Schultz were published. In particular, they attempted to use the idea of the "value" of human capital in the practice of managing education and skills of the workforce. During this period, the economy actively expanded into sociology, cultural studies, and computer science [20].

Based on many years of research on the theory of human capital, L. Thurow summarized its results. "People's human capital is their ability to produce goods and services" [21]. According to this interpretation, a person who does not realize these abilities also has human capital. At the same time, L. Thurow noted that the possession of human capital is not an innate property of a person. Natural inclinations, abilities of a person are considered by him as a factor in the formation and accumulation of human capital [22]. 
the volume of workload, especially in fundamental and humanitarian disciplines. Human capital includes both special and general knowledge and skills. The value of human capital can be measured even in monetary terms. Its size is determined by the amount of investment in education, health care, etc. [26]. In this regard, Russia lags far behind a number of developed countries and China.

\section{REFERENCES}

[1] W. Petty, Economic and statistical works, Moscow: Sotsekgiz, 1940, $324 \mathrm{p}$.

[2] A. Smith, Research on the nature and causes of the wealth of peoples, Moscow: Sotsekgiz, 1956, p. 490.

[3] Anthology of economic classics, Vol. 1, Moscow, 1993, P. 308.

[4] Anthology of economic classics, Vol. 1, Moscow, 1993, P. 310.

[5] V. Y. Elmeev, Work man instead of human capital, in: V. V. Partsvaniya (Ed.), Human Perspectives in a Globalizing World, SPb.: Saint Petersburg philosophical society, 2003, pp. 319-351.

[6] L. Walras, Etudes d'economie politique appliquee: ou Theorie de la production de la richesse sociale, Losanne, 1898.

[7] J.M. Clark, Economic Institutions and Human Welfare, N. Y., 1957.

[8] E. N. Roussakis, F. List, The Zollverein, and the Uniting of Europe, Bruges, 1968.

[9] On the beginning, successes, special subjects, and the importance of political economy, Moscow, 1934.

[10] Foundations of political economy, St. Petersburg, 1865 .

[11] A. Marshall, Principles of political economy, Vol.1., Moscow: Progress, 1993, P.124.

[12] T. Schultz, Capital Formation by Education, in Journal of Political Economy, University of Chicago Press, Vol.68, no.6, 1960, pp. 571-583.

[13] T. Schultz. Investment in Human Capital, in American Economic Review, Vol.51, No.1 (March, 1961), pp. 1-17.

[14] G. S. Becker, Investment in Human Capital: A Theoretical Analysis, in Journal of Political Economy, Vol. 70, 9, 1962, pp. 9-49. 
[20] O. Nordhoug, Human Capital in Organizations: Competence, Training and Learning, Oslo: Scandinavian University Press, 1993.

[21] L. Thurow, The future of capitalism. How today's economic forces shape tomorrow's world, Novosibirsk: Siberian chronograph, 1999, $432 \mathrm{p}$.

[22] L. Thurow, Investment in Human Capital, Belmont, 1970, pp. 116-117.

[23] R. I. Kapelyushnikov, The concept of human capital, in Criticism of modern bourgeois political economy, Moscow: Nauka, 1977.

[24] M. M. Kritsky, Human capital, Leningrad: Leningrad University Publishing House, 1991, p. 17.

[25] Theodor W. Schultz, The economic value of education, N. Y., 1963.

[26] C. Goldin, Human Capital, in: C. Diebolt, M. Haupert (eds.), Handbook of Cliometrics, Heidelberg, Germany: Springer-Verlag, 2016. DOI 10.1007/978-3642-40406-1_23 